\title{
Content of capsaicin extracted from hot pepper (Capsicum annuum ssp. microcarpum L.) and its use as an ecopesticide
}

\author{
Liljana Koleva Gudeva ${ }^{1}$, Sasa Mitrev ${ }^{1}$, Viktorija Maksimova ${ }^{2}$, Dusan Spasov ${ }^{1}$ \\ ${ }^{1}$ Goce Delcev University, Faculty of Agricultural Sciences, Stip, Macedonia \\ ${ }^{2}$ Goce Delcev University, Faculty of Medical Sciences, Stip, Macedonia
}

\begin{abstract}
The latest world trends in scientific research are directed towards the production of secondary metabolites, their use and application. Capsaicin, the pungent principle of hot peppers is one of the best-known natural compounds. Nowadays, research has been focusing the influence of capsaicin on physiological and biochemical processes of humans, animals, and recently plants as a biopesticide. Phytochemical studies of Capsicum annuum L. increase the application of secondary metabolites in pharmacy, food technology and medicine. In this paper, the possibilities of utilization of Capsicum annuum ssp. microcarpum L. for extracting capsaicin and its use as a biopesticide against the green peach aphid Myzus persicae Sulz. in pepper culture are summarized. The content of capsaicin was evaluated spectrophotometrically, and the ability of capsaicin for acting as biopesticide was calculated according to Abbott. Results showed that oleoresin from Capsicum annuum ssp. microcarpum L. and its dilution 1:20 are the most efficient as a biopesticide. From these results we can say that this kind of peppers can be used as a raw material for extraction of capsaicin, because of its high concentration and efficiency.
\end{abstract}

Keywords: capsaicinoids, ethanol extraction, oleoresin, biopesticides.

PROFESSIONAL PAPER

UDC 664.521:615.322:66

Hem. Ind. 67 (4) 671-675 (2013)

doi: 10.2298/HEMIND120921110K

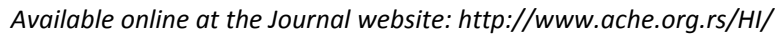

Secondary plant metabolites represent a significant economic group used in different areas such as production of food additives, pigments, pharmacuticals and biopesticides [1]. The most important components in the group of secondary metabolites, derived from the biologically active components of the species Capsicum annum L. are the group of alkaloids-capsaicinoids.

Capsaicinoids are derivates of benzylamin. Differences within their structure depend mainly on their acyl moieties, and three structural elements are involved: first, the length of the acyl chain (C8-C13), then the way it terminates (linear, iso or anteiso-series), and the presence or absence of unsaturation at the $\omega$-3(capsaicin type) or $\omega-4$ carbon atom (homocapsaicin type I and II) $[2,3]$.

Capsaicin, a homovanillic acid derivative (8-methyl- $N$-vanillyl-6-nonenamide, Figure 1 ), is an active component of the red pepper. The level of the capsaicin in the seasonal pepper is around $0.025 \%$, and in the hot pepper around $0.25 \%[4,5]$.

It is an extraordinarily versatile agent, and its use in a variety of fields ranges from pharmacology and nutrition to chemical weapons and shark repellence. Cap-

Correspondence: V. Maksimova, Goce Delcev University, Faculty of medical sciences, Krste Misirkov str. bb, P.O. Box 201, 2000 Stip, Macedonia.

E-mail: viktorija.maksimova@ugd.edu.mk

Paper received: 21 September, 2012

Paper accepted: 26 November, 2012 saicin is represented with $69 \%$ in the group of capsacinoids; dihydrocapsacinoids with $22 \%$; nordihydrocapsacinoids with 7\%; homocapsaicin and homohydrocapsaicin takes only $1 \%$ in the group of capsaicinoids. Capsaicin and dihydrocapsaicin being approximately twice as pungent as nordihydrocapsaicin and homocapsaicin and they are responsible for the hotness of the pepper. The pungency of capsaicinoids and pepper containing preparations can be expressed in Scoville Heat Units (SHU) and the human palate can detect it even diluted in $1: 17000000$ ratio $[2,3,6]$.<smiles>COc1cc(CNC(=O)CCCC/C=C/C(C)C)ccc1O</smiles>

Figure 1. Structural formula of capsaicin.

Because of the antimicrobial capacity of the capsaicin, Walter (1995), for the first time, suggested a protective medium that contains capsaicin, as a base component in the product that belongs to the group of biochemical pesticides. From 1995 onwards, a lot of products have been registered in the EPA (Environmental Protection Agency, USA), insecticides and rodenticides based on capsaicin. In the end of 2001, the EPA registered around 195 active materials as biopesticides and 780 products [7]. 
Because of great interest and the complex nature of the research aimed to examine the character of the biopesticides, they are categorized into three major classes: microbial pesticides, protective elements, and biochemical pesticides. Biopesticides are natural substances made from herbal extracts or from pheromones from insects, which in the control of the pests have no toxic effect. Capsaicin belongs to the third class of biopesticides [8-10].

It is important to note that capsaicin-containing products have primarily been used to repel insects since ancient times. Literature survey has revealed that capsaicin has lethal and antifeedant effects on various invertebrates, which is another reason why organic farming is directed toward the production of biopesticides $[9,11]$. The aim of this experiment is to examine the relationship between the concentration of capsaicin and its activity as a biopesticide.

\section{EXPERIMENTAL}

\section{Plant material for extraction of capsaicin}

Dried fruits of hot pepper Capsicum annuum ssp. microcarpum L. were used for extraction of capsaicin (Figure 2).

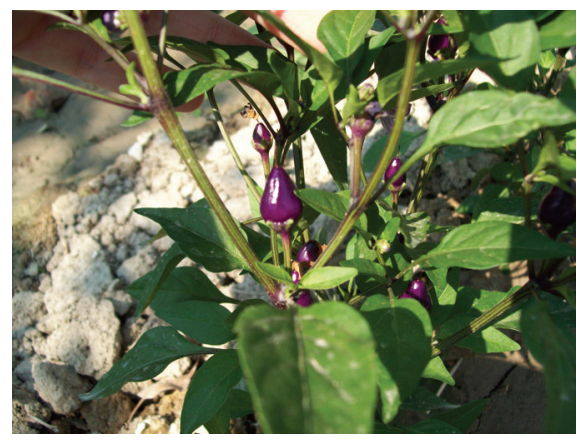

Figure 2. Habitus of hot pepper, Capsicum annuum ssp. microcarpum, in the phase of fruiting.

The seed of the hot peppers from the breed "Bonbona" was taken from the gene bank at the Faculty of Agricultural Sciences, Strumica, Macedonia. The peppers were grown in an open field area, which was situated in the region of Strumica $\left(41^{\circ} 26^{\prime} 15^{\prime \prime} \mathrm{NGW}\right.$ and $22^{\circ} 38^{\prime} 35^{\prime \prime}$ EGL). They were collected in late September, in the phase of botanical maturity [12]. The fruits were dried in a Binder dryer at a temperature of $50{ }^{\circ} \mathrm{C}$ until constant weight. The dried material was powdered in a blender (Gorenje SIC400B).

\section{Plant material for testing the efficiency of capsaicin extraction}

The examinations for determining the efficiency of capsaicin as biopesticide were made in closed conditions on another type of pepper culture from the breed
Inferno, which was infected with the plant louse of Myzus persicae Sulz (Figure 3).

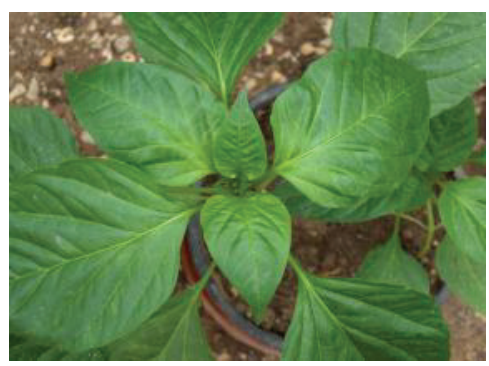

(a)

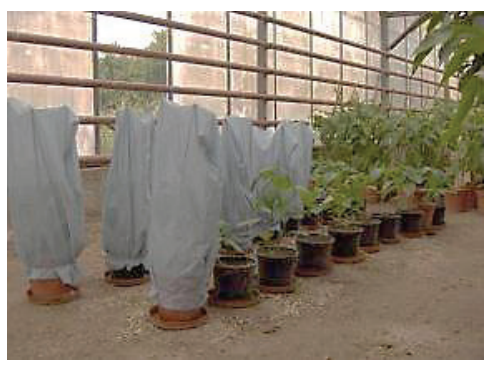

(b)

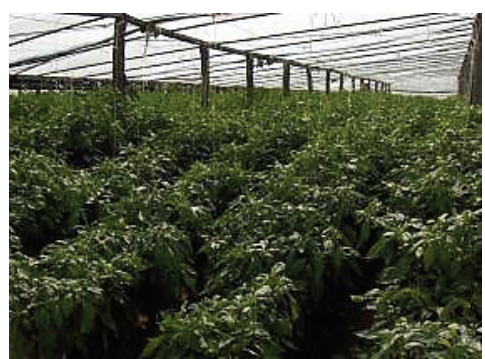

(c)

Figure 3. Pepper Capsisum annuum L. breed Inferno grown in a greenhouse under controlled conditions. a) Apical bud of pepper host plant infected with Myzus persicae Sulz.; b) Infected host plants covered with trap bag; c) Pepper production breed Inferno.

The infection was formed on the apical buds of the host plant right before the phase of initial flowering. The initial infection on the hosting plant is given in Figure 3a. In order to enable better and faster development of the plant louse, and also to prevent the spreading of the infection to the other plants, the infected samples were covered with trap bags (Figure $3 b)$. The procedure for controlling the efficiency of the extract of capsaicin was repeated three times on the same infected plants. Infected plants were treated in the period of 14 days after the initial infections. Treated plants were in the phenological phase of full flowering, when the eggs of the plant louse and adult forms of the parasite were noted on the leafs.

In the other case of growing peppers, the presence of plant-louse of Myzus persicae Sulz. was also noticed in the early fruiting phase on pepper fruits. These plants were infected without any artificial infection. 
The same treatment was used in this case, where capsicum oleoresin and variant 1 and 2 (Table 1) were used as the treatment solution.

Table 1. Capsaicin concentration in oleoresin and its dilutions

\begin{tabular}{lcc}
\hline Variant & Rate of dilution & $\begin{array}{c}\text { Capsaicin } \\
\text { concentration, } \mathrm{mg} / \mathrm{ml}\end{array}$ \\
\hline Oleorasin & - & 12.2375 \\
1 & $1: 2$ & 6.1187 \\
2 & $1: 10$ & 1.2237 \\
3 & $1: 20$ & 0.6118 \\
4 & $1: 50$ & 0.2447 \\
5 & $1: 125$ & 0.0998 \\
6 & $1: 625$ & 0.0167 \\
\hline
\end{tabular}

\section{Methods of work}

Capsicum oleoresin can be prepared from hot peppers using a variety of organic solvents, but ethanol is the only one suitable for obtaining pharmaceutical grade material [3]. The dried and smashed material from hot pepper Capsicum annuum ssp. microcarpum L. was kept into desiccators and this material was used for obtaining the capsicum oleoresin. Extraction was performed with $96 \%(\mathrm{v} / \mathrm{v})$ ethanol from dry plant material (0.1-0.5 g of powdered plant material was taken for extraction), in a water bath using a temperature of 40 ${ }^{\circ} \mathrm{C}$, within a period of $5 \mathrm{~h}$. Then, water vacuum filtration was included in the experiment for obtaining an ethanol extract of capsaicin. The obtained oleoresin had a concentration of $12.712 \mathrm{mg}$ capsaicin/ml extract.

After obtaining the basic oleoresin, six dilutions were made for treatment of the plants (Table 1) with the aim of determining the effects of different concentration of capsaicin in the diluted samples. Dilutions were made ex tempore, before the treatment of infected plants, and sterile distillated water was used as a control.

Capsaicin and analogs were detected at $100 \mathrm{ng}$ level by UV monitoring at $279 \mathrm{~nm}$ [8]. The absorbance of capsaicin, in the proper dilutions of the ethanol extract, was measured spectrophotometrically (UV/Vis Varian 50) at a wave length of $281 \mathrm{~nm}$ [13].

The standard curve (Figure 4) was made with standard dilution (0.02-0.1 mg/ml) of capsaicin (Sigma), and the coefficient of the linear correlation (Figure 5) was $R^{2}=0.998(y=9.7734 x+0.1409)$.

\section{Testing of the effectiveness of capsaicin as an ecopesticide}

The second part of this study, aimed to determine the relationship between content of capsaicin and it use as a biopesticide, was conducted on pepper from the breed Inferno, which was infected with aphis Myzus persicae Sulz. Three replicates of the infection were maintained for each concentration along with the control. The evaluation of the efficiency of the active material was based on the number of infected leaves with aphis. The results of the efficiency of the capsaicin as biopesticide were measured in 24 hours, and calculated according to Abbott's formula [14]:

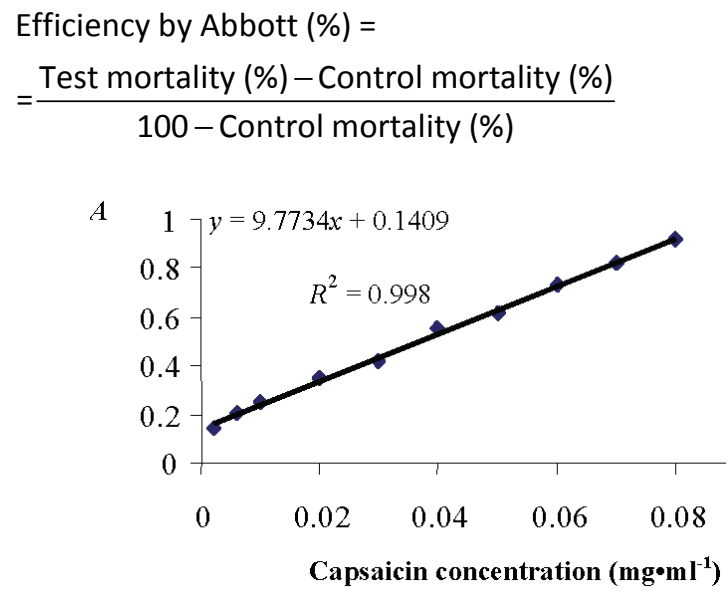

Figure 4. Capsaicin standard curve at $281 \mathrm{~nm}$.

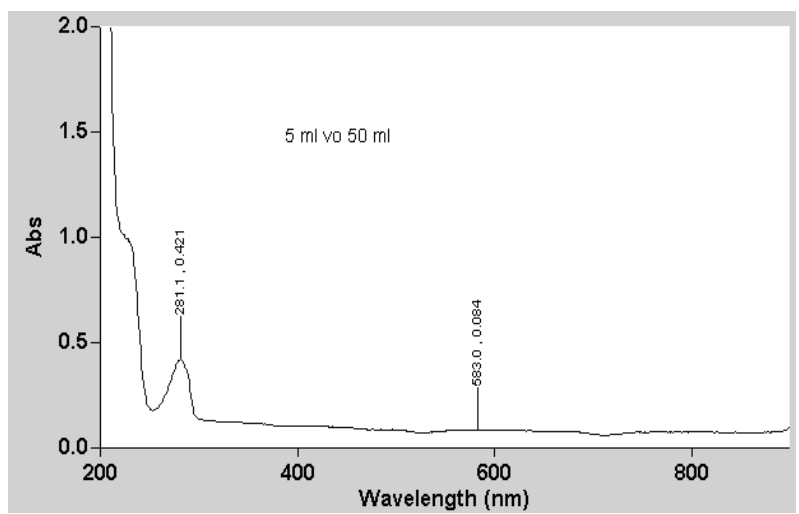

Figure 5. UV/Vis spectra of capsaicin standard (Sigma) with typical peak at $281 \mathrm{~nm}$.

The efficiency of capsicum oleoresin and variant 1 and 2 on the accidentally infected plants in the phase of fruiting was also evaluated as a demonstration of their activity as biopesticides.

\section{RESULTS AND DISCUSSION}

The content of capsaicin in the oleoresin dilutions is given in Table 1. As expected, the results confirmed the highest concentration of capsaicin in the oleoresin, and a 700 times lower concentration in the last diluted sample.

The intensity of the aphis attack on the pepper was high, with a large number colonies formed. The treatment of the pepper, with all the research variants, depending on the concentration of the capsaicin in the dilution, gave a different effect (Table 2). 
Table 2. Efficiency of the capsaicin in appropriate dilutions according to Abbott after 24 hours of the treatment on the pepper

\begin{tabular}{|c|c|c|c|c|c|}
\hline Variant & $\begin{array}{c}\text { No. of leaves infected } \\
\text { with Aphids }\end{array}$ & $\begin{array}{c}\text { No. of Aphids before } \\
\text { treatment }\end{array}$ & $\begin{array}{l}\text { No. of Aphids after } \\
\text { treatment }\end{array}$ & Control & Efficiency by Abbott, \% \\
\hline Oleorasin & 3 & 132 & 2 & 78 & 97.4 \\
\hline 1 & 3 & 118 & 6 & 66 & 90.9 \\
\hline 2 & 3 & 76 & 5 & 51 & 90.1 \\
\hline 3 & 3 & 77 & 13 & 48 & 72.9 \\
\hline 4 & 3 & 38 & 21 & 36 & 41.7 \\
\hline 5 & 3 & 49 & 13 & 21 & 38.1 \\
\hline 6 & 3 & 37 & 20 & 21 & 4.8 \\
\hline
\end{tabular}

The results obtained in this experiment, once again confirmed concentration/dose dependent increase in larvicidal activity, according to the literature [15]. The largest efficiency in the repression of the aphis on the pepper is observed at oleoresin with $97.4 \%$, where the capsaicin concentration is $12.2374 \mathrm{mg} / \mathrm{mL}$. Its activity drops gradually until the last dilution.

$L C_{50}=0.2934 \mathrm{mg} / \mathrm{mL}$ is concentration that is achieved with dilution of 1:50. This means that the concentration of capsaicin in oleoresin and first two dilutions (variants 1 and 2 with efficiency from 97.4-90.1\%) is high enough to kill $90 \%$ of the insects, and in third variant the concentration is enough to kill $50 \%$ of parasites. In the next three variants, dilution is very high and the concentration of the capsaicin is in the range of 0.2447 to $0.0167 \mathrm{mg} / \mathrm{mL}$, so the smallest effect of this dilution is completely understandable. The highest concentration, in contrast with the smallest, is 20.3 times more efficient. From the results it is obviously that capsaicin showed high efficiency with larvicide and adulticide capacity, but only if it is in proper concentration. We can say that the dose and efficiency are linearly dependent (Figure 6) for the first three concentration of capsaicin.

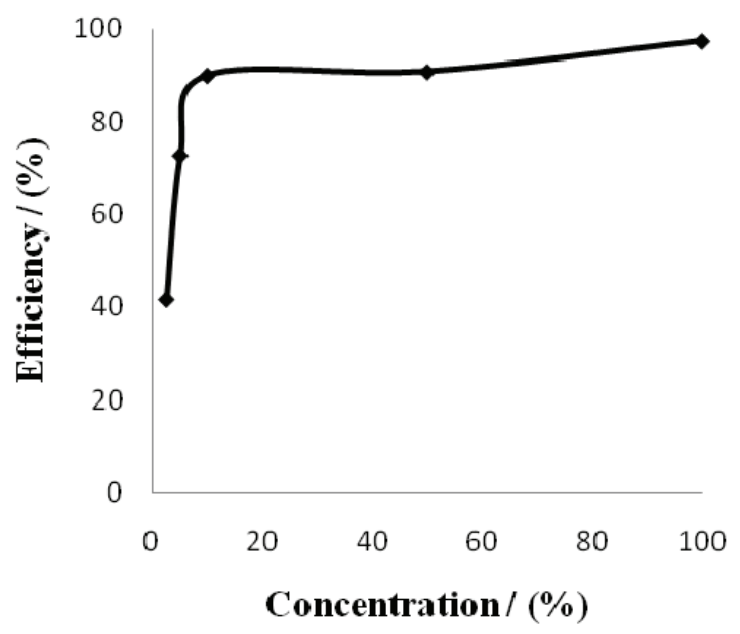

Figure 6. Concentration dependent efficiency of capsaicin against Mayzus persicae Sulz.

\section{CONCLUSION}

The everyday use of different types of pesticides makes the aphis Myzus persicae Sulz. more resistant to today's products. On the other hand, the written records point to the use of new products as biopesticides in control and repression of pests, especially popular in organic production. This resulted in efforts to find a new natural and safety way to protect plants from insects and parasites.

The experimental results confirmed that the examined pepper contains a high concentration of capsaicin. It can be widely used as material for extracting capsaicin. Its oleoresin can be used as an effective biopesticide along with its dilutions even to the rate of 1:20.

The aim of this study was to make a chemical and insecticide characterization of oleoresin extracted from Capsicum annuum ssp. microcarpum, giving an emphasis on quantitative information about the concentration of capsaicin in different variants, and correlation with its activity as a biopesticide.

\section{REFERENCES}

[1] A. Sasson, Production of useful biochemicals by higherplant cell cultures: biotechnological and economic aspects, CHIEAM, Options Mediterraneennes 14 (1991) 59-74.

[2] A. Brossi, The alkaloids, Chemistry and pharmacology, Academic Press, Orlando, FL, 1984, pp. 228-286.

[3] E. Fattorusso, O.Taglialatela-Scafati, Modern alkaloids: structure, isolation, synthesis and biology, Wiley, Weinheim, 2008, pp. 73-104.

[4] B. Lazić, Povrtarstvo, Paprika (Capsicum annuum L.), Poljoprivredni fakultet, Univerzitet u Novom Sadu, Jugoslavija, 1995 (in Serbian).

[5] P. Holzer, Capsaicin: cellular targets, mechanisms of action, and selectivity for thin sensory neurons. Pharmacol. Rev. 43 (1994) 143-201.

[6] D. De Witt, The nature of capsaicin, The Chile Pepper Encyclopedia, HarperCollins Publishers, New York, 1999.

[7] Environmental Protection Agency, USA, http:// //www.epa.gov/ 
[8] T. Aniszewski, Alkaloids-secrets of life: Alkaloid Chemistry, Biological Significance, Applications and Ecological Role, Elsevier, Amsterdam, 2007, pp. 205-214.

[9] R.K. Sinha, G. Hahn, P.K. Singh, R.K. Suhane, A. Anthonyreddy, Organic Farming by Vermiculture: Producing Safe, Nutritive and Protective Foods by Earthworms, Am. J. Exp. Agric. 1(4) (2011) 363-399.

[10] W.R. Walter, Wax and Capsaicin based pesticide, Wilder Agricultural Product Co Inc., New Wilmington, PA, 1995.

[11] A.P. Madhumathy, A.-A. Aivazi, V.A. Vijayan, Larvicidal efficacy of Capsicum annum against Anopheles stephensi and Culex quinquefasciatus, J. Vect. Borne Dis. 44 (2007) 223-226.
[12] V.S. Govindarajan,. Capsicum - production, technology, chemistry and quality - Part I. Botany, cultivation and primary processing, CRC Cr. Rev. Food Sci. 22(2) (1985) 109-176.

[13] V.S. Govindarajan, Capsicum- production, technology, chemistry and quality - Part II. Processed products, standards world production and trade, CRC Cr. Rev. Food Sci. 23(3) (1985) 207-288.

[14] W.S. Abbott, A method of computing the effectiveness of an insecticide, J. Econ. Entomol. 18 (1925) 265-267.

[15] P.M.E. Ubulom, N.G. Imandeh, C.E. Udobi, I. Ilya, Larvicidal and Antifungal Properties of Picralima nitida (Apocynaceae) Leaf Extracts, Eur. J. Med. Plants 2(2) (2012) 132-139.

\section{IZVOD}

\section{SADRŽAJ KAPSAICINA U LUUTOJ PAPRICI (Capsicum annuum ssp. microcarpum L.) I NJEGOVA PRIMENA KAO BIOPESTICIDA}

Liljana Koleva Gudeva ${ }^{1}$, Sasa Mitrev ${ }^{1}$, Viktorija Maksimova ${ }^{2}$, Dusan Spasov ${ }^{1}$

${ }^{1}$ Goce Delcev University, Faculty of Agricultural Sciences, Stip, Macedonia

${ }^{2}$ Goce Delcev University, Faculty of Medical Sciences, Stip, Macedonia

(Stručni rad)

Alkaloidi dugo vremena predstavljaju predmet istraživanja u organskoj hemiji i farmakologiji, zbog svoje biološke i fiziološke aktivnosti uslovljene hemijskom strukturom. Kapsaicinoidi su grupa alkaloida, koji se javljaju kao kompleksne mešavine acil konjugata na vanilamin u rodu Capsicum. U ovom eksperimentu je korišćena vrsta paprike Capsicum annuum ssp. microcarpum koja predstavlja jednu od najljućih sorti koje se proizvode u Makedoniji. Iz paprike je izolovan kapsaicin, čija je koncentracija određivanja spektrofotometrijski. Uzimajući u obzir da je u poslednje vreme malo podataka o kapsaicinu kao biopesticidu, u radu je ispitan uticaj kapsaicina, kao i njegove koncentracije, na larve i adultne parazitske organizme Myzus periceae Sulz. Rezultati istraživanja su pokazali da je capsaicin efikasan biopesticid protiv Myzus periceae Sulz., jer je $L C_{50}=0,2934 \mathrm{mg} / \mathrm{ml}$, i da je njegova aktivnost direktno zavisna od koncentracije. Najveća aktivnost kapsaicina kao biopesticida je u opsegu koncentracija od 1,2237 do $12,2375 \mathrm{mg} / \mathrm{ml}$, pri kojima se postiže efikasnost od 90,1-97,0\%. Dobijeni rezultati opravdavaju upotrebu ove vrste paprike kao sirovine za ekstrakciju kapsaicina, kao i upotrebu kapsaicina kao biopesticida za navedenu vrstu organizama.

Ključne reči: Kapsaicinoidi • Ekstrakcija etanolom • Oleoresin • Biopesticidi 